\title{
THE LAST WOLF. THOMAS HOBBES' PHILOSOPHY OF CRIME AND PUNISHMENT
}

Silvia Alves ${ }^{1}$

\section{Abstract}

This article describes and analyses Thomas Hobbes' philosophy of crime and punishment. In Leviathan or Philosophical rudiments (De Cive), political science, legal theory and philosophy of crime and punishment compose a coherent unity. This scenario where power and law emerge allows to erect an extraordinarily modern theory that shelters preference for statutory law and suspicion of judicial discretion; consistency and predictability of the legal system; preventism and utilitarianism on punishments; prohibition of ex post facto laws and, in general, defence of strict legality. Boldness and the disconcerting frankness of Hobbes' thinking coexist with some defiant antinomies. The duty to obey never eclipses the inalienable right to self-preservation. And the theorist of absolute sovereignty sometimes appears to be an unexpected liberal. However, perhaps the most disturbing feature to today's reader is the permanent reminder that punishment remains pure violence. The right to punish and the right to resist are the brutal remains of the state of nature.

\section{Keywords}

Thomas Hobbes. Legal positivism. Theory of punishment. Principle of legality. Enemy criminal law (Feindstrafrecht). Right of resistance.

\section{Summary}

1. The scenario: 'bobbisme' and law. 2. The foundation of ius puniendi or the 'last wolf'. 3. The aims of punishments. 4. The criminal law. 4.1. Law, authority and justice. 4.2. Law, right and liberty. 4.3. Criminal laws and errors of the sovereign. 4.4. The principle of legality. 5. Judges, when 'clubs are trumps'... 6. The enemy. 7. Duty to obey and liberty to resist.

1 Associate Professor of the University of Lisbon Faculty of Law. silviaalves@fd.ulisboa.pt 
'Force should be right; or rather, right and wrong,

Between whose endless jar justice resides,

Should lose their names, and so should justice too.

Then every thing includes itself in power,

Power into will, will into appetite; And appetite, an universal wolf,

So doubly seconded with will and power,

Must make perforce an universal prey, And last eat up bimself.'

William Shakespeare, Troilus and Cressida, Act I. Scene III

\section{THE SCENARIO: 'HOBBISME' AND LAW}

The personality traits attributed to Thomas Hobbes (1588-1679) are very revealing of the ambiguities and misconceptions of his work and the very different interpretations that it has generated. ${ }^{2}$ In this man who claimed to have been born as the twin brother to fear, intellectual boldness contrasted with physical panic. ${ }^{3}$ Diderot (1713-1784), who dedicated an article in the Encyclopédie to bobbisme, paid tribute to the fruitful originality of his thinking, noting that even his errors served the progress of the human spirit more than a host of works filled with common truths. ${ }^{4}$

Hobbes' theory of crime and punishment develops against the backdrop of his political 'science', the 'foundation' of which he claims in the 'Epistle Dedicatory' of The Elements of Law Natural and Politic, and of his legal theory that conceives law as a product of the State, free from the constraints of a higher law. In fact, Hobbesian jus-rationalism presents us with an immutable natural law which in reality is not considered true law because, in the state of nature, there is no guarantee that its rational

2 This text is an updated version of the article entitled 'Filosofia penal de Thomas Hobbes', published in Revista Brasileira de Estudos Políticos, 2015, 75-122.

${ }^{3}$ TRUYOL Y SERRA 2007, 218.

${ }^{4}$ DIDEROT 1765, 240. 
principles of conduct will be obeyed. The rules of natural law ('law of nature' or 'lex naturae') are merely moral in character rather than legal; they 'are not properly laws, but qualities that dispose men to peace and to obedience' (Leviathan, Ch. 26, 4). ${ }^{5}$ The main impact of supra-positive law the restriction of political power and of its law - therefore disappears. Neither does Hobbes conceive the relationship between positive law and natural law as potentially antagonistic, contradicting tradition: 'civil and natural law are not different kinds, but different parts of law; whereof one part, being written, is called civil, the other unwritten, natural.' (Leviathan, Ch. 26, 4). ${ }^{6}$ The natural law may dispose men to obedience, but it is the civil law (i.e. positive law) that converts its rules into true law and guarantees they are observed. Underestimating the value of the content of law, Hobbes becomes a founder ${ }^{7}$ and ultimate defender of legal positivism and, more precisely, of legalistic positivism.

Law has its origin in the State - 'The legislator, in all Commonwealths, is only the sovereign' (Leviathan, Ch. 26, 1) ${ }^{8}$ - and is the pure expression of the will of the State. Nothing is just or unjust in itself, but an artificial creation of that will. Surprisingly in the context of the coeval legal order, inevitably pluralist, Hobbes is entirely coherent in identifying reason with law, by means of an innovative presentation of the framework of the sources of law. Legal theory or jurisprudence ('jurisprudentia') and judicial precedents are purely and simply pulverized. In fact, he 'assailed the very foundations of the common lawyers' system'. 'The horror of differences of opinions and of uncertainty, a theme that would be so dearly loved by eighteenth century thinking, foresees the final identification of law with the State. The law of the sovereign ignores or eliminates contradictions,

${ }^{5}$ HOBBES 2012, 418.

${ }^{6}$ HOBBES 2012, 418.

7 VILLEY 2003, 559.

${ }^{8}$ HOBBES 2012, 416.

${ }^{9}$ LOBBAN 2012, 58. 
but wise men 'that study and observe with equal time and diligence the reasons and resolutions are, and must remain, discordant' (Leviathan, Ch. $26,7) .{ }^{10}$ With regard to precedents, no room is left for doubts: any 'subordinate judge' may make a mistake and, 'if afterward in another like case he find it more consonant to equity to give a contrary sentence, he is obliged to do it' (Leviathan, Ch. 26, 8). ${ }^{11}$ And no 'man's error becomes his own law, nor obliges him to persist in it' (Leviathan, Ch. 26, 8). ${ }^{12}$ Custom, the force of which over time was undeniable, is redirected to the (tacit) will of the sovereign: it is not the length of time that maketh the authority, but the will of the sovereign signified by his silence (for silence is sometimes an argument of consent)' (Leviathan, Ch. 26, 3). ${ }^{13}$ Hobbes' theory of crime is built for the State and by means of its legal order.

Fortune du système de Hobbes - La théorie du droit de Hobbes entraîne une Révolution. Alors que son programme politique, favorable à l'absolutisme, n'a guère trouvé que des adversaires dans le cercle de 'philosophes' modernes, le schéma central du système, le renversement d'Aristote, la négation de la 'nature politique' de l'bomme, l'artificialité du droit, sa réduction au texte de la loiet aussi la libération de la tradition cléricale - devaient avoir une telle fortune que nous en portons encore le poids. ${ }^{14}$

\section{THE FOUNDATION OF IUS PUNIENDI OR THE 'LAST WOLF'}

a. 'By what door the right or authority of punishing, in any case, came in'?: Hobbes answers his question by seeing the right to punish as an own right of the sovereign, not therefore being transferred by individuals by means

\footnotetext{
${ }^{10}$ HOBBES 2012, 422.

11 HOBBES 2012, 432.

12 HOBBES 2012, 432.

13 HOBBES 2012, 416.

14 VILLEY 2006, 110.
} 
of a social covenant (Leviathan, Ch. 28). ${ }^{15}$ This is undeniably the understanding that has garnered greatest support in the wording of his texts, although some have found a 'normative foundation' for the ius puniendi, either by means of an 'authorisation' to punish others or, in an admittedly minority position, by means of an 'authorisation' to punish oneself. ${ }^{16}$ 'The right which the Commonwealth (that is, he or they that represent it) hath to punish is not grounded on any concession or gift of the subjects (...) For the subjects did not give the sovereign that right' (Leviathan, Ch. 28). ${ }^{17}$

Despite not resulting from any concession or 'gift', the foundation of the right to punish is still somewhat contractualistic. It is rooted in the right to everything and in the right to do all that is necessary for self-preservation, which only the sovereign preserves. It therefore already exists in the state of nature and, not being a creation of the social state, is transformed by agreement, gaining an artificial nature. Actually, a similar metamorphosis occurs in relation to the purely artificial right to make laws. Indeed, the great Leviathan, the State, the Commonwealth, the Civitas is nothing other than an 'Artificial Man'; sovereignty is an 'Artificial Soul; and justice and laws, 'an artificial Reason and Will (Leviathan, Introduction). ${ }^{18}$ The ius puniendi is exercised by means of the (civil) law and Hobbes systematically separates punishment from acts of hostility. Samuel von Pufendorf (16321694) highlights this impossibility of a precise overlap between the natural right to do everything to guarantee self-preservation and the right to punish, in his critique of Hobbes' opinion: these rights would be different, since the latter is exercised over subjects, and this condition does not exist in the state of nature. Pufendorf also observes that the philosopher from

${ }^{15}$ HOBBES 2012, 482.

16 SCHROCK 1991, 859; YATES 2012, 153.

${ }^{17}$ HOBBES 2012, 482.

${ }^{18}$ HOBBES 2012, 16. 


\section{Sílvia Alves |TheLastWolf| ISSN 2675-1038}

Malmesbury rejects any foundation of the right to punish based on consent. $^{19}$

But I have also shewed formerly, that before the institution of Commonwealth, every man had a right to everything, and to do whatsoever he thought necessary to his own preservation; subduing, hurting, or killing any man in order thereunto. And this is the foundation of that right of punishing which is exercised in every Commonwealth (Leviathan, Ch. 28). ${ }^{20}$

Given that this right to do anything only belongs to the sovereign, it is not a transfer but a surrender that explains the right to punish in the social state, or a power 'vacuum'. ${ }^{21}$ The sovereign is the 'last wolf, ${ }^{22}$ the only one who maintains intact the wolf's right to everything and to do everything. The right to punish was not given, but left to the sovereign - 'so that it was not given, but left to him, and to him only' (Leviathan, Ch. 28). ${ }^{23}$ This passing to the social state hence gives rise to a fundamental change: with their surrender, men dramatically strengthen the position of the sovereign. It is precisely this abdication that leads to the disappearance of the original equality and places them in safety, because natural equality does not allow one to claim an advantage to which another may not aspire (Leviathan, Ch. 13). ${ }^{24}$ Notwithstanding the differences between men, no-one is in a position not to fear even the weakest. Herbert Hart (1907-1992) highlighted this 'approximate equality' between men when setting out the

19 PUFENDORF 1706, 240.

${ }^{20}$ HOBBES 2012, 482.

${ }^{21}$ YATES 2012, v.g. 118.

22 BLOCH 1967, 60.

${ }^{23}$ HOBBES 2012, 482.

${ }^{24}$ HOBBES 2012, 188. 
'minimum content' of natural law. ${ }^{25}$ 'For the subjects did not give the sovereign that right; but only, in laying down theirs, strengthened him to use his own as he should think fit for the preservation of them all' (Leviathan, Ch. 28). ${ }^{26}$

The ius puniendi, even though transformed into law by the alchemy of the social covenant, remains as a remnant or vestige of the state of nature and of war itself. As has been seen, a deep contradiction can be noted: either the retention of power that is transformed into the right to punish is implicitly or tacitly approved by men, or, there being no consent, as Hobbes formally claims, all punishment is a return to the state of nature. The main function of the State is the protection of men but it is also a 'weapon of war'. The sovereign is, ultimately, a 'double agent'. ${ }^{27}$ Nevertheless, the surrender that renders it all powerful also has, underlying it, in part, a legal basis by means of the authorisation to punish others. Hobbes himself, when listing the rights of sovereigns, states that the right to punish is trusted (or 'committed') to the sovereign (Leviathan, Ch. 18, 51). ${ }^{28}$ Punishment is simultaneously a right and a fact or act of violence. $^{29}$

b. The social covenant implies that individuals give up the right to defend others and gain the obligation to help the sovereign punish them. This does not imply, however, that they surrender the right to defend themselves. They thus retain the right to resist violence. 'No man is supposed bound by Covenant, not to resist violence (...) every man giveth

${ }^{25}$ HART 2012, 195.

${ }^{26}$ HOBBES 2012, 482.

${ }^{27}$ NORRIE 1984, 308.

${ }^{28}$ HOBBES 2012, 276.

${ }^{29}$ RISTROPH 2009, 613. 
away the right of defending another; but not of defending himself (Leviathan, Ch. 28). ${ }^{30}$

Each man is obliged to help the sovereign in punishing others but not himself. In fact, no-one has the right to punish himself. Since they do not hold such a right, individuals could never transfer it. 'But to covenant to assist the Sovereign in doing hurt to another, unless he that so covenanteth have a right to do it himself, is not to give him a Right to Punish' (Leviathan, Ch. 28). ${ }^{31}$

What are the meaning and consequences of retaining the right to resist violence and, therefore, punishment by the State? The right to defend oneself seems to be cancelled out by the sovereign's right to do everything and to receive the support of the others. It is the mere and total imbalance between the position of the State and that of individuals that gives effect to the power to punish (others). This is an exclusive and almost unlimited power: '(excepting the limits set him by natural law) as entire as in the condition of mere nature, and of war of every one against his neighbour' (Leviathan, Ch. 28). ${ }^{32}$

This does, however, raise a difficulty: if the right to resist violence remains with individuals and if punishment results from an impossibility - merely factical - of carrying out that resistance, the social state, with regard to the punishment of crimes, is still a state of war and this war does not break out simply because the position of the contenders is highly unequal. The subject is punished like the army that surrenders and submits at the sight of the overwhelmingly greater strength of the enemy. The right to punish and the right to resist violence make the position of the State and the positon of the convicted person equal in legal terms and it is the total imbalance between their strengths that is concentrated in the power to

30 HOBBES 2012, 482.

${ }^{31}$ HOBBES 2012, 482.

32 HOBBES 2012, 482. 
punish (others), received and counting on the cooperation of all, and the right to resist violence that presides over the administration of criminal justice. Punishment represents the clash between two mortals with the same rights. ${ }^{33}$ In this duel between the subject and the sovereign, Hobbes' effort to separate punishment from war and penalties from acts of hostility appears to be defeated.

\section{THE AIMS OF PUNISHMENTS}

a. Hobbes' modernity is manifest when he announces the preventism and utilitarianism that would dominate criminal legal thought in the second half of the eighteenth century. ${ }^{34}$ Yet, some have found in his work a simultaneous and contradictory outline of modern retributivism and utilitarianism and, consequently, the core of his thinking for the subsequent development of the philosophy of punishment. ${ }^{35}$ In a somewhat more literal reading, Hobbes loses interest in retribution and therefore in the past, with which, in fact, he associates remembering the wild and brutal state. ${ }^{36}$ Revenge is indeed revenge against time ${ }^{37}$ and Hobbes considers that natural law imposes on penalties a prospective purpose or 'some future good' (Leviathan, Ch. 28). ${ }^{38}$ 'The end of punishing is not revenge and discharge of choler, but correction either of the offender or of others by his example' (Leviathan, Ch. 30). ${ }^{39}$

One of the rules of natural law expressly listed determines that in 'revenge' - or retribution of harm with harm - the past evil is not contemplated, but

${ }^{33}$ RISTROPH 2009, 615.

${ }^{34}$ CATTANEO 1965, 289; TZITZIS 1984, 303.

${ }^{35}$ NORRIE 1984, 319 and 320.

36 TZITZIS 1984, 297.

37 ZAFFARONI 2007, 48.

${ }^{38}$ HOBBES 2012, 492.

${ }^{39}$ HOBBES 2012, 542. 
the future good (special and general deterrence): correction of the offender and the example to others (Leviathan, Ch. 15 and Ch. 30; Philosophical Rudiments, Ch. 3, 11; Elements of Law, Ch. 3, 10). ${ }^{40}$ Penalties are intended to predispose to obedience - 'disposing the delinquent or, (by his example), other men to obey the laws' (Leviathan, Ch. 28). ${ }^{41}$ They are not regarded, in their essence, as a requirement of justice, the balance of which would be redressed, in line with the traditional image. All punishments are laid down for the 'benefit of the Commonwealth', that is, 'to the forming of men's wills to the observation of the law' (Leviathan, Ch. 28). ${ }^{42}$ The penal system includes therefore the discipline of obedience.

While, on the one hand, this perspective moves us dangerously towards a political transpersonalism that threatens to see men as a mere instrument of power, on the other hand, it cannot be denied that Hobbes continues to bear in mind a concern for limiting the actions of the holder of the ius puniendi and, once again, the safety of subjects. In fact, the primary purpose of penalties is so identified with their essence that not achieving this brings with it the consequence of not considering other punishments as a true penalty and classing them as an act of war - 'because without such an end, no hurt done is contained under that name' (Leviathan, Ch. 28). ${ }^{43}$ In other words, 'preventist' utilitarianism draws the boundary of the power itself. Useless or unnecessary evils that are imposed on men represent war. Penalties belong to the world of peace and law.

b. For Hobbes, prevention (deterrence) is accomplished through fear. He does not deviate here from the traditional perspective. The criminal law of the Ancien Régime gave penalties an essentially retributive purpose, but did not ignore specific deterrence (of religious inspiration) and, above all,

40 HOBBES 2012, 232 and 542; HOBBES 1841, 37; HOBBES 1840a: 100 and 101.

41 HOBBES 2012, 484.

${ }^{42}$ HOBBES 2012, 492.

${ }^{43}$ HOBBES 2012, 484. 
general deterrence. Even with humanitarian reformism, the 'beneficial terror' ('salutare terrore') of penalties ${ }^{44}$ would preserve their purpose: to keep men in 'peaceable and virtuous conversation by terror' (Elements of Law, Ch. 5,11$):{ }^{45}$ 'the aim of punishment is not a revenge, but terror' (Leviathan, Ch. 28). ${ }^{46}$

Fear is the passion that makes men tend less towards committing crimes. Its political potential lies, therefore, in the fact that it is a driver of obedience to the laws and the reason they are effective. Never greatly optimistic, Hobbes states: '(excepting some generous natures) it is the only thing (when there is appearance of profit or pleasure by breaking the laws) that makes men keep them' (Leviathan, Ch. 27). ${ }^{47}$ Like a watchmaker, the lawmaker must have precise knowledge of the workings of human nature. Paradoxically, fear of punishment, instilled in some, ought to guarantee the tranquillity of the rest ${ }^{48}$. The penal system is not for the most part aimed at criminals and the potentially corrupt, but at all.

c. Obedience, which is part of the observance of laws, can be correlated with protection. Power is established to guarantee safety and this is provided as long as there is obedience. 'All sovereign power is originally given by the consent of every one of the subjects, to the end they should as long as they are obedient, be protected thereby' (Leviathan, Ch. 28). ${ }^{49}$

While 'constant peace' between nations cannot be achieved because there is no super-Leviathan or 'common power' in this world to punish their injustices, a durable 'peace at home' can be achieved if the 'common people' are convinced of the advantages of obedience and the harm that

\footnotetext{
44 BECCARIA 1764, 69; ALVES 2014, 33 and 34.

45 HOBBES 1840a, 116.

46 HOBBES 2012, 486.

47 HOBBES 2012, 464.

48 TZITZIS 1984, 297.

${ }^{49}$ HOBBES 2012, 492.
} 
can befall them if they join those who deceive them with promises of reformation or change of government. ${ }^{50}$ To achieve this durable but precarious and self-interested peace (utilitarianism), Hobbes is not expecting any individual calculation of the advantages and disadvantages, but rather that the clergy will assume this particular duty: to educate for obedience.

Peace is not, therefore, a pure consequence of the social covenant, but a permanent conquest resulting from interest and threat. It is not seen as static, but dynamic, as a constant political problem. Obedience and safety are thus two essential parts of the great synallagmatic social covenant: the power offers safety and receives obedience; the subjects give obedience and receive protection. Punishments are the guarantee of peace and an instrument of social control, the safety of all and the cement of power.

\section{THE CRIMINAL LAW}

\subsection{Law, authority and justice}

a. The Hobbesian concept of law is essentially voluntaristic and relativistic. Law is a manifestation of the will of the sovereign, an order or command (Philosophical Rudiments, Ch. 14, 1). ${ }^{51}$ Hence it is different from mere counsel (Leviathan, Ch. 26). ${ }^{52}$ To be more precise, it is defined as a command from him or them that have the sovereign power, aimed at him or they who are the subjects, declaring publicly and clearly what they may do, and what they must refrain from doing. ${ }^{53}$ Hobbes is exhaustive in clarifying any doubt on the understanding that the law is produced exclusively by the sovereign: 'The legislator in all Commonwealths is only

50 HOBBES 1840b, 8.

${ }^{51}$ HOBBES 1841, 182 and 183.

52 HOBBES 2012, 414.

53 HOBBES 1840b, 26. 
the sovereign'; 'the Commonwealth is the legislator' (Leviathan, Ch. 26, 1). ${ }^{54} \mathrm{~A}$ consequence of voluntarism is a bold indifference to the content of the law (relativism) that is a hallmark of positivism. It is not wisdom or truth, but authority that makes the law. ${ }^{55}$

This total handing over of the law to the State, a pure human task free of the political constraints of a higher law which must be obeyed, is not, however, free or without limits. The law remains an essential part of the balance in the political game, since it is the instrument or means needed to guarantee the peace and well-being of man in the present world. ${ }^{56}$ The aim of all human law is peace and justice among the men of each nation and defence against foreign enemies. ${ }^{57}$ Hobbes recognises the traditional view of political power as an officium, disconnecting the power-holder from those who benefit from its exercise, the people - 'God made Kings for the people, and not people for Kings' ${ }^{58}$ Of course, it is the sovereign who will decide what is best for his people; and of course the sovereign answers only to God Almighty. ${ }^{59}$ The fear of God is therefore the only bridle of the Kings of England. ${ }^{60}$

b. Hobbes rejects the Aristotelian concept of law that leads to the production of a 'covenant' or 'common consent'. Such a conception would not apply, in the first place, to divine law and natural law. If that were true, those laws could be revoked or amended by consensus, but this theory is not possible, due to their immutable nature. The idea of a covenant does not apply to civil law either because the foundation of its obligatory nature is a promise. A contract is a promise that can be

\footnotetext{
${ }^{54}$ HOBBES 2012, 416.

${ }_{55}$ HOBBES 1840b, 5.

${ }^{56}$ HOBBES 1840b, 9.

${ }^{57}$ HOBBES 1840b, 8.

${ }^{58}$ HOBBES 1840b, 13.

${ }^{59}$ HOBBES 1840b, 14.

${ }^{60}$ HOBBES 1840b, 32.
} 
expressed using the formula ' $\mathrm{I}$ will do this'; conversely, the law is a command that imposes 'Do this'. While 'contracts oblige us, laws tie us fast, being obliged', that is, the law forces the subject to comply by means of the threat of the use of force or fear of punishment. By contracts, we are obliged; by law, we are tied to our obligation. In this passage, which Hobbes felt the need to clarify in a note, he brings together, with regard to the law, the reason for obedience and the foundation of obligatoriness, as if a contract obliged by a promise and the law by the threat of force or power to coerce, when the latter in reality guarantees its effectiveness. 'Law ties him being obliged, that is to say, it compells him to make good his promise, for fear of the punishment appointed by the Law' (Philosophical Rudiments, Ch. 14, 2). ${ }^{61}$

Nevertheless, Hobbes also refers to the general covenant of obedience (to the power and its laws) by which the subject is obliged, even before knowing what his obligations will be. And, in fact, the law in its proper sense only exists with the 'supreme power'. The power to coerce is the shackle that ties the subject to the law. The order that the law includes is obeyed by virtue of the threat, because the subject is compelled by fear of the penalty. The laws in their own sense are 'living and armed'. ${ }^{62}$ It is the strength rather than the justice of their rules that guarantees they are effective: it is not what the law says ('the word of the law') but the power of a man who has the strength of a nation that makes the laws effective ('effectual'). The law arises from will, obliges by virtue of a general covenant of obedience - 'universal Contract of yeelding obedience' (Philosophical Rudiments, Ch. 14, 2) ${ }^{63}$ - and is imposed by force.

c. Hobbes inverts the ancestral relationship between justice and law. The natural disputes regarding 'meum and tuum, right and wrong, good and bad'

${ }^{61}$ HOBBES 1841, 185.

${ }^{62}$ HOBBES 1840b, 10.

${ }^{63}$ HOBBES 1841, 185. 
are overcome by means of the civil law that determines the 'common measure' to be followed (Elements of Law, Ch. 1, 10; Ch. 10, 8). ${ }^{64}$

Conformity between the natural law - paradigm of the just law - and the civil law results from the specific rule of natural law that imposes respect for the given word. By means of the social covenant, subjects are obliged to obey the sovereign and his aws, even before these are passed and their determinations are known (Philosophical Rudiments, Ch. 14, 10). ${ }^{65}$ The possibility of a contradiction between reason and the written law is rejected: 'nothing is more reasonable than that every man should obey the law which he hath himself assented to'. The issue of conformity between the content of a written law and the content of the natural law does not really interest Hobbes. His aim is rather to demonstrate that the natural law imposes obedience to the civil law, and that underlying the civil law is the consent of individuals. ${ }^{66}$

The social covenant serves to make it clear that the lawmaker and the duty of obedience predate the laws, and that the laws predate justice and injustice. ${ }^{67}$ In other words, the precedence of the law means that it is the law that determines what is just (human justice). What is a good law, Hobbes asks in Leviathan: 'By a good law, I mean not a just law: for no law can be unjust' (Leviathan, Ch. 30). ${ }^{68}$ There is nothing considered unjust that would not be contrary to a law: 'Where there is no common power, there is no law; where no law, no injustice' (Leviathan, Ch. 13). ${ }^{69}$ It is not a prior idea of justice that conditions the content of the law, but the content of the law that enables the distinction between what is just and unjust. By means of civil law, the sovereign transmits to the subjects the rules that

\footnotetext{
${ }^{64}$ HOBBES 1841, 131 and 225.

65 HOBBES 1841, 190.

${ }^{66}$ HOBBES 1840b, 64.

${ }^{67}$ HOBBES 1840b, 29.

${ }^{68}$ HOBBES 2012, 540.

${ }^{69}$ HOBBES 2012, 196.
} 
will be used as the criteria to distinguish between right and wrong (Leviathan, Ch. 26): ${ }^{70}$ 'laws are the rules of just and unjust' (Leviathan, Ch. 26). ${ }^{71}$

As John Austin (1790-1859) noted, justice and injustice now have a variable and relative meaning and the civil law will be its own criterion: no positive law is (legally) unfair.

It is affirmed by Hobbes, in his masterly treatises on government, that 'no law can be unjust:' which proposition has been deemed by many, an immoral or pernicious paradox. If we look at the scope of the treatises in which it occurs, or even at the passages by which it is immediately followed, we shall find that the proposition is neither pernicious nor paradoxical, but is merely a truism put in unguarded terms. His meaning is obviously this: that 'no positive law is legally unjust.' And the decried proposition, as thus understood, is indisputably true. For positive law is the measure or test of legal justice and injustice: and, consequently, if positive law might be legally unjust, positive law might be unjust as measured or tried by itfelf. $^{72}$

It follows from this that a just action is an action that is not against the law. ${ }^{73}$ And crimes are a creation of statute laws. Therefore, Hobbes explains, although the natural law prohibits theft and adultery, if the civil law orders by some chance the prohibited conduct, these will cease to be considered crimes (Philosophical Rudiments, Ch. 14, 10). ${ }^{74}$ The relationship between natural law and civil law is not considered from the perspective of

${ }^{70}$ HOBBES 2012, 414.

${ }^{71}$ HOBBES 2012, 416.

72 AUSTIN 1995, 217, note.

${ }^{73}$ HOBBES 1840b, 29.

${ }^{74}$ HOBBES 1841, 191. 
a potential conflict and, therefore, with a concern to resolve theoretical issues (validity) and practical issues (obedience) resulting from any possible mismatch. There is continuity between the two: 'The law of nature and the civil law contain each other, and are of equal extent' (Leviathan, Ch. 26, 4). ${ }^{75}$ The State, like King Midas, performs its alchemy that transform natural laws into true laws, guaranteeing they are obeyed (power to coerce). Hobbes considers it pertinent to examine the laws, that is, that which they command and that which they prohibit, but does not raise the issue of whether they are just ("not dispute of their justice" ${ }^{\text {76 }}$ ). Justice and natural law do not serve the political purpose of opening up the issue of the right of resistance, but, on the contrary, that of requiring compliance with positive law.

\subsection{Law, right and liberty}

a. Hobbes disagrees with the identification of law (lex) with right (jus): 'I find the words lex civilis and jus civile, that is to say, law and right civil, promiscuously used for the same thing, even in the most learned authors; which nevertheless ought not to be so' (Leviathan, Ch. 26). ${ }^{77}$ Laws restrict natural liberty: firstly divine law and natural law, secondly civil law. At first glance, law is therefore the enemy of liberty. In fact, civil law has to be in line with the supra-positive laws; it cannot allow that which they prohibit, or prohibit that which they permit. But civil laws - subordinate and inferior - can extend the scope of the restrictions defined by the superior laws. Right is the natural liberty that the laws leave. Law and right ("lex and jus') are for Hobbes, hence, competing concepts like obligation and liberty (Leviathan, Ch. 14; Elements of Law, Ch. 10, 5). ${ }^{78}$ Laws are shackles and right is liberty.

75 HOBBES 2012, 418.

${ }^{76}$ HOBBES 1840b, 146.

${ }^{77}$ HOBBES 2012, 450.

${ }^{78}$ HOBBES 2012, 198; HOBBES 1840a, 222. 
For Right is Liberty, namely that liberty which the civil law leaves us: but Civil Law is an Obligation, and takes from us the Liberty which the Law of Nature gave us. Nature gave a Right to every man to secure himself by his own strength, and to invade a suspected neighbour by way of prevention: but the Civil Law takes away that Liberty, in all cases where the protection of the Law may be safely stayed for. Insomuch as Lex and Jus are as different as Obligation and Liberty' (Leviathan, Ch. 26). ${ }^{79}$

For law is a fetter, right is freedom; and they differ like contraries (Philosophical Rudiments, Ch. 14, 3). ${ }^{80}$

'My right' is the liberty left me to do that which the law does not prohibit me from doing and not to do that which the law does not command me to. ${ }^{81}$ Liberties depend on the silence of the law (Leviathan, Ch. 21). ${ }^{82}$ Deprivation of liberty brought about by the civil laws - and, with it, the power to define and punish crimes (ius puniendi) - is the price of safety and peace in society.

b. The civil law includes 'two parts', corresponding to the lawmaker's two functions, 'to judge' and to oblige or 'constrain': distributive and vindicative or penal (Philosophical Rudiments, Ch. 14, 6; Leviathan, Ch. 26). ${ }^{83}$ And Hobbes stresses: it is not a question of two kinds of law, but two parts of the same law (Philosophical Rudiments, Ch. 14, 7). ${ }^{84}$ The first allocates to each person his right ('proper right'; 'the rights of the subjects'), determines that which belongs to each of them, that is, their

\footnotetext{
${ }^{79}$ HOBBES 2012, 450.

${ }^{80}$ HOBBES 1841, 186.

${ }^{81}$ HOBBES 1840b, 30.

82 HOBBES 2012, 340.

${ }^{83}$ HOBBES 1841, 188; HOBBES 2012, 442.

${ }^{84}$ HOBBES 1841, 188.
} 
property ('the mine and the yours') and that which it is lawful or unlawful to do or omit. The second establishes the penalties to be applied to those who break the laws. Without the threat of punishment, 'proper order' will be useless or in vain. In this way the criminal law includes two commands, aimed at different recipients. The first, distributive and prohibitory, prohibits the offence and is aimed at all subjects. The second is a particular command, designed to be vindicative, that establishes penalties for those who breach the prohibition and is aimed at judges and, in general, ministers and officials who are responsible for enforcing the law ('is mandatory, and only speaks to public ministers'; 'public ministers appointed to see the penalty executed'). This order is not aimed at the delinquent since he cannot be expected to faithfully punish himself (Leviathan, Ch. 26; Elements of Law, Ch. 10, 6). ${ }^{85}$

c. This interpretation of criminal law that divides it into two commands, with two different intended recipients, allows Hobbes to reject punishment as the 'price' of crime (Philosophical Rudiments, Ch. 14, 23), ${ }^{86}$ or permission to do harm, remission or atonement of sin, redemption of natural liberty. As if the law in fact did not prohibit the behaviour, but proposed a 'licence' to commit crime. The prohibition would be conditional in nature - you will do no harm, or otherwise suffer the punishment - and would be aimed only at those who escaped punishment. In the Hobbesian interpretation, which may favour a moralistic vision of criminal law, ${ }^{87}$ the prohibitive part of the law prohibits absolutely and the vindicative part is not available to the delinquent since it is aimed at the judge.

4.3. Criminal laws and errors of the sovereign

${ }^{85}$ HOBBES 2012, 442; HOBBES 1840a, 224.

${ }^{86}$ HOBBES 1841, 201.

87 TZITZIS 1996, 19. 
a. The monopoly over the ius puniendi given to the Leviathan does not stop Hobbes from providing a preliminary reflection on the errors of the sovereign, both as a lawmaker, and as the body responsible for administering criminal justice. In both roles, confusing messages that the sovereign gives the subjects lead to consequences.

With regard to the criminal laws, the concerns listed are similar to the eighteenth century scienza della legislazione. Hobbes criticises bad laws and goes on to provide general conclusions on lawmaking. The issues identified are raised in relation to the legal measure of punishments. Preventism also proves to be in operation in the area of the measure of penalties, imposing an exact measure beyond which the sovereign is then performing acts of hostility and below which it establishes a mere price for the crime. Any error in this complex utilitarian accounting implies that criminal justice has been abandoned. Excessive or modest punishments are not true penalties. While the former declare war on the subject, the latter do not dispose men to obedience. If the harm inflicted is less than the desired benefit of the crime - 'is rather the Price or Redemption' (Leviathan, Ch. 28) ${ }^{88}$ - it ends up being an invitation to commit crime. And the protection of legality bars the possibility of correcting the punishment by judicial means. The lawmaker selects and decides not only as a careful watchmaker, who has precise knowledge of the workings of human nature, but also as a painstaking accountant who establishes the exact measure of the punishments.

b. Errors may extend to the administration of criminal justice. The sovereign has the duty to punish crimes. Examples of impunity, undoubtedly the most evident of those errors, send a message that Hobbes does not approve of and from which he draws consequences: they provide the hope of mercy and encourage criminality. The sovereign

${ }^{88}$ HOBBES 2012, 484. 
has 'his part' in the offences committed and should not, therefore 'charge the offender with the whole' (Leviathan, Ch. 27). ${ }^{89}$

In other cases, the sovereign sends contradictory messages. Hobbes alludes to behaviour that the law expressly condemns, but that the lawmaker 'by other manifest signs of his will tacitly approveth'. Since the law is the expression of the legislator's will, 'there appear in this case two contradictory laws'. He gives the example of duels which, although punished by law, leave those who refuse a duel subject to common contempt, and sometimes regarded by the sovereign as unworthy of performing a commanding position in war. Hobbes makes a not particularly clear distinction between the law and the lawmaker, probably intending the first to mean a right (recta) will demonstrated abstractly and the second a specific will that is not detached from facts and circumstances. Not without some irony, he observes: 'though it be our duty to do, not what they do, but what they say; yet will that duty never be performed till it please God to give men an extraordinary and supernatural grace to follow that precept'. But the sovereign has the duty not to sanction anything obliquely which it directly forbids and he is in part a cause of the transgression' - 'therefore cannot reasonably impute the whole crime to the delinquent'. In similar cases, the crime becomes less and 'part of the fault may be discharged on the punisher' (Leviathan, Ch. 27). ${ }^{90}$ A strict punishment should not be applied ('he ought not in reason to be rigorously punished').

Two conclusions can be drawn from Hobbes' reflection. Firstly, criminal law may be the expression of the will of the supreme power, but that will is not unlimited or arbitrary. It must be politically driven since it produces political and legal consequences which hold it accountable. Secondly, errors of the sovereign do not befall the subjects. More than a defender of

${ }^{89}$ HOBBES 2012, 472.

${ }^{90}$ HOBBES 2012, 475-476. 
the absolute monarchy, Hobbes is once again here the twin brother of fear.

\subsection{The principle of legality}

a. Hobbesian criminal legality is truly clear, complete and pioneering, above all if we consider that, during the second half of the eighteenth century, the fight against judicial discretion (arbitrium judicis) and the defence of legality are two of the most important themes that the reformist plan of humanitarianism has yet to deal with. The 'change of the criminal law paradigm' is then, in fact, 'much more an "evolution" than a (French and American) "revolution"". "Crime is defined as an 'offense' that is against the law and for which a penalty is ordained, ${ }^{92}$ this having been previously established (Leviathan, Ch. 18). ${ }^{93}$ While legality represents peace and protection of the citizen's safety, breach of it leads Hobbes to use the language of war.

i) Nullum crimen sine lege: 'A CRIME is a sin consisting in the committing (by deed or word) of that which the law forbiddeth, or the omission of what it hath commanded' (Leviathan, Ch. 27). ${ }^{94}$

ii) Nulla poena sine lege: 'A PUNISHMENT is an evil inflicted by public authority on him that hath done or omitted that which is judged by the same authority to be a transgression of the law, to the end that the will of men may thereby the better be disposed to obedience' (Leviathan, Ch. 28). ${ }^{95}$

\footnotetext{
${ }^{91}$ MARTYN 2013, 10.

92 HOBBES 1840b, 37.

93 HOBBES 2012, 276.

${ }^{94}$ HOBBES 2012, 452.

${ }^{95}$ HOBBES 2012, 482.
} 


\section{Sílvia Alves |TheLastWolf| ISSN 2675-1038}

iii) Nullum crimen, nulla poena sine lege praevia: 'harm inflicted for a fact done before there was a law that forbade it is not punishment, but an act of hostility: for before the law, there is no transgression of the law' (Leviathan, Ch. 28). ${ }^{96}$

iv) Nulla poena sine judicium: 'the evil inflicted by public authority, without precedent public condemnation, is not to be styled by the name of punishment, but of a hostile act, because the fact for which a man is punished ought first to be judged by public authority to be a transgression of the law' (Leviathan, Ch. 28). ${ }^{97}$

For Hobbes, the legality and non-retroactivity of the criminal law are a guarantee of its rationality. In A Dialogue between a Philosopher and a Student of the Common Laws of England, he trusts in the adequacy of punishments determined and made public prior to a crime being committed. In such conditions, we might even grant any man authority to define penalties; it would be 'right reason' establishing them. Therefore, it is obviously reasonable that, having broken 'the known laws', man suffers the known penalties. ${ }^{98}$ The Lanyer agrees, also opposing to punishment in the absence of a 'precedent law', arbitrary laws, and, also, arbitrary punishments. ${ }^{99}$

b. Hobbes' modernity is revealed when he outlines as a criterion for determining penalties in law proportionality between the harm of the crime and the harm of the penalty. The law of the Ancien Régime was not unfamiliar with the idea of proportionality, but this was often used by the lawmaker as a means of making punishments harsher, when criminality failed to cede and the penalties in law were thought not to be sufficient.

${ }^{96}$ HOBBES 2012, 486.

${ }^{97}$ HOBBES 2012, 484.

${ }^{98}$ HOBBES 1840b, 122.

${ }^{99}$ HOBBES 1840b, 123. 
Proportionality of penalties as a mechanism of moderation and a criterion for building a calibrated system of crimes and penalties was to become a dogma with humanitarianism.

In Dialogue, on the subject of heresy, Hobbes comments on Edward Coke (1552-1634) and the condemning of Bartholomew Legat (c.1575-1612) to death by burning for Arianism. Since Hobbes considers that death by burning had been abolished when the laws contemplating it were repealed, he appeals to the law of reason and to proportion between the 'mischief which the doctrine maketh and the mischief to be inflicted'. This proportion must be 'measured' only by who has the 'charge of governing the people', that is, the King and, if the punishment affects life or limb, the King with the assent of Parliament. ${ }^{100}$

c. Legality remains untouchable, even when the penalty of the law proves inadequate. Hobbes does not allow 'correction' of punishments by the judge when the law includes a given punishment. Defining the punishment that is politically correct or appropriate to serve its purpose is a strict duty of the lawmaker, to be met by means of a previously established law. The sovereign power is responsible for the message of the law and even for the criminality that it 'invites' with insufficient penalties. 'For the punishment foreknown, if not great enough to deter men from the action, is an invitement to it' (Leviathan, Ch. 27). ${ }^{101}$

The expectation that a known law will be applied cannot be frustrated and neither, therefore, may the message of the law be misleading. The subject's safety trumps the public interest of a rational and useful penalty.

when men compare the benefit of their injustice with the harm of their punishment, by necessity of nature they choose that which appeareth best for themselves: and therefore when they are

100 HOBBES 1840b, 109.

101 HOBBES 2012, 456. 
punished more than the law had formerly determined, or more than others were punished for the same crime, it is the law that tempted and deceiveth them (Leviathan, Ch. 27). ${ }^{102}$

The criminal law of the Ancien Régime saw legal or ordinary penalties (poenae ordinariae) and arbitrary or extraordinary penalties (poenae extraordinariae), based on the faculty given to the judges to modify or vary the penalties in law (arbitrium judicis), as being complementary. This flexibility made it possible to seek the fair penalty for the specific case, update the law in force or even adjust punishments to the level of criminality. ${ }^{103}$ Hobbes anticipates the eighteenth century reformists and, to some extent, the science of legislation - which places in statute law all expectations of legal progress -, not only when he outlines the field of action of judicial discretion, but also when he considers that the lawmaker must make good laws; and these laws may be responsible for crimes; and even when he shows he is aware that the law is a powerful political instrument. Lastly, his modernity with what may be considered a liberal foresight is revealed in the way safety is achieved. The fight against criminality does not arise as a justification for forgetting rights, as is typical of authoritarianisms. Hobbes' concern sets the priority on the boundary within which the sovereign power acts.

d. Although he considers that harm imposed without a prior law is not a penalty but an act of war, we also find that Hobbes admits a penalty without law, and arbitrary penalties. He does so not without some, at least apparent, contradiction, insofar as he defines crime precisely by means of the threat of criminal sanctions, freeing the State from any material concept of crime (malum in se). Crime is that which the State says is crime. However, he does state 'where there is no punishment at all determined by

102 HOBBES 2012, 456.

103 ALVES 2014, 773-789. 
the law, there whatsoever is inflicted hath the nature of punishment' (Leviathan, Ch. 28). ${ }^{104}$ Accordingly, he also muddies the waters on the nonretroactivity of criminal law: 'when the law that forbiddeth a fact is made before the fact be done, yet he that doth the fact is liable to the penalty ordained after, in case no lesser penalty were made known before, neither by writing nor by example' (Leviathan, Ch. 27). ${ }^{105}$

Hobbes forestalls any foreseeable criticism when he considers that the application of an arbitrary punishment does not upset legal certainty, since there is no failure to meet an expectation regarding the application of a known punishment. On the contrary, his understanding is that if the legislation does not determine any punishment, the subject has every reason to expect an arbitrary punishment. 'He that goes about the violation of a law, wherein no penalty is determined, expecteth an indeterminate, that is to say, an arbitrary punishment' (Leviathan, Ch. 28). ${ }^{106}$

Indeed, the offender does not have to know the exact punishment determined by the law and, therefore, ignorance of the penalty excuses noone, since those who voluntarily perform an action accept all of its consequences, the 'known consequences'. What is known is the inevitability of punishment, because the law, which is not a mere collection of 'vain words', necessarily implies it. The law would be worth nothing if it could be broken with impunity (Philosophical Rudiments, Ch. 14, 8). ${ }^{107}$ A law 'without a fear of penalty' is not a law, 'but vain words' (Leviathan, Ch. 27). ${ }^{108}$ In short, the subject could only think that those consequences are implied by the law that charges him. It is not the exact and precise penalty that must be known. If the punishment is determined in the law, it is that

104 HOBBES 2012, 486.

105 HOBBES 2012, 458.

106 HOBBES 2012, 486.

107 HOBBES 1841, 189.

${ }^{108}$ HOBBES 2012, 456. 
to which he is subject. Otherwise, the offender must consider himself subject to an arbitrary punishment. 'Punishment is a known consequence of the violation of the laws in every Commonwealth' (Leviathan, Ch. 27). ${ }^{109}$

The basis for applying an arbitrary punishment in the absence of a legal provision lies, for Hobbes, in the reciprocity of will. Like a mirror, the penalty appears as a reflection of the crime. The epicentre of crime and of punishment, as of law in general, is to be found in will. Crime results from voluntary behaviour. Punishment results from the will of the sovereign. Contrary to the conception of punishment as vengeance, what comes to the surface here is however the idea of retribution or punishment as a response to crime, a response of restoring the balance. 'For it is reason that he which does injury, without other limitation than that of his own will, should suffer punishment without other limitation than that of his will whose law is thereby violated' (Leviathan, Ch. 27). ${ }^{110}$

The penalty is therefore invariably incorporated in the civil law, whether explicitly or implicitly. If the penalty is not defined in writing or by means of an example, one may infer that it must be arbitrary, that is dependent on the will of the sovereign (Philosophical Rudiments, Ch. 14, 8). ${ }^{111}$ The legislator must, in such cases, be consulted.

This interpretation diminishes to a large extent the principle of the legal penalty - or may lead this to be considered purely and simply absent ${ }^{112}-$ but Hobbes' work has to be understood in the context of the general admissibility of judicial discretion and, insofar as he defends consulting the lawmaker in such cases, the arbitrariness he accepts is to some extent legal and mitigated. It may not go on to its primary rejection, but the original contribution lies precisely in the way it limited judicial discretion.

109 HOBBES 2012, 456.

110 HOBBES 2012, 456.

${ }^{111}$ HOBBES 1841, 189.

112 SOTO 2013, 696 and 704. 
e. The non-retroactivity of the incriminating rule is not weakened, even if the crime also represents an offence against natural law. The (natural) law may be prior to the act performed, but the transfer of this into civil or positive law and the publicising of this are, for Hobbes, a condition for it to become obligatory.

The legality and, more precisely, the non-retroactivity of criminal law produce very specific consequences, insofar as the law establishes the maximum limit of the punishment, thereby preventing its exacerbation or the possibility of being condemned to a penalty greater than that determined in the law via the arbitrary power of the judges. 'If a punishment be determined and prescribed in the law itself, and after the crime committed there be a greater punishment inflicted, the excess is not punishment, but an act of hostility' (Leviathan, Ch. 28). ${ }^{113}$

The limitation represented by the non-retroactivity of the criminal law thus extends to punishments determined by sources of law other than legislation. The penalty usually applied represents the traditional domain of judicial discretion, where 'interpretations' of the jurists (jurisprudentia), which actually constituted the most noble and scientific part of criminal law, and customary justification, via repetition and antiquity, also come into play. Non-retroactivity therefore limits the judge's choice of punishments, also incorporating (another) (legal) limit regarding the maximum of the arbitrary penalty.

The main aim of penalties justifies this facet of legality. Since the purpose of punishment is not retribution as vengeance but deterrence as terror and terror of an unknown penalty does not exist, the 'unexpected addition' is not, therefore, part of the punishment (Leviathan, Ch. 28). ${ }^{114}$ When a penalty is either annexed to the crime in the law itself, or hath been usually

113 HOBBES 2012, 486.

${ }^{114}$ HOBBES 2012, 486. 
inflicted in the like cases, there the delinquent is excused from a greater penalty' (Leviathan, Ch. 27). ${ }^{115}$

\section{JUDGES, WHEN ‘CLUBS ARE TRUMPS’...}

a. According to a centenary understanding, Hobbes differentiates between the ownership and the exercise of the power to judge. In Dialogue, he accuses Edward Coke of a fallacy, by confusing 'committing' and 'transferring'. The power to judge has not been transferred and therefore has not ceased to belong to the sovereign. ${ }^{116}$ The latter simply 'commits' the exercise of this power to judges, and these judge cases in the sovereign's name and under his authority. A judicial ruling is, therefore, still a ruling of the sovereign. And for the same reason the monarch remains the competent body to resolve conflicts of jurisdiction, which are so frequent. ${ }^{117}$

In all courts of justice, the sovereign (which is the person of the Commonwealth) is he that judgeth: the subordinate judge ought to have regard to the reason which moved his sovereign to make such law, that his sentence may be according thereunto, which then is his sovereigns sentence; otherwise it is his own, and an unjust one (Leviathan, Ch. 26, 7). ${ }^{118}$

b. Hobbes outlines the profile of a 'good judge', focusing his activity on interpreting the law. The exceptional qualities that he claims are required of this servant of the State approximate him to Hercules, the judge 'of

115 HOBBES 2012, 456.

116 HOBBES 1840b, 52.

${ }^{117}$ HOBBES 1840b, 54.

118 HOBBES 2012, 422. 
superhuman intellectual power and patience', ${ }^{119}$ imagined by Ronald Dworkin (1931-2013). He must have a good command of the principal law of nature or equity, he must acquire superior knowledge and wisdom, and he must be impartial, patient and generally unaffected by human passions. But this being, who is so distant from the common man, will never be afforded even the most tenuous possibility of creating law. He has the strict and difficult task of 'discovering' the law produced by the State.

The things that make a good judge or good interpreter of the laws are, first, a right understanding of that principal law of nature called equity; which, depending not on the reading of other men's writings, but on the goodness of a man's own natural reason and meditation, is presumed to be in those most that had most leisure, and had the most inclination to meditate thereon. Secondly, contempt of unnecessary riches and preferments. Thirdly, to be able in judgement to divest himself of all fear, anger, hatred, love, and compassion. Fourthly, and lastly, patience to hear, diligent attention in hearing, and memory to retain, digest, and apply what he hath heard (Leviathan, Ch. 26). ${ }^{120}$

In an appreciation that may be considered proto-sociological of the status of judges, variable remuneration of the judicature, established in line with the 'multitude of causes', is deemed to be harmful for the State. This leads to two inconvenient situations: multiplication of cases ('the nourishing of suits'), 'for the more suits, the greater benefit'; and disputes as to the competent jurisdiction or 'contention about jurisdiction' (Leviathan, Ch. 28). ${ }^{121}$

119 DWORKIN 1998, 239.

${ }^{120}$ HOBBES 2012, 438.

${ }^{121}$ HOBBES 2012, 496. 
c. Unsurprisingly, yet boldly, Hobbes condemns the automatic repetition of decisions and rejects judicial precedent, which only proves what was done and not what was well done. ${ }^{122}$

But because there is no judge subordinate, nor sovereign, but may err in a judgement equity; if afterward in another like case he find it more consonant to equity to give a contrary sentence, he is obliged to do it. No man's error becomes his own law, nor obliges him to persist in it (Leviathan, Ch. 26). ${ }^{123}$

d. Interpretation is certainly one of the areas in which Hobbes reveals more of his modernity and coherence. He anticipates the emphatic criticisms of the eighteenth century when he warns of the risks of differences in interpretation and the craftiness of the interpreters. But he does not open easy or unrealistic pathways. For that reason, he does not defend or even suggest that interpretation be prohibited and he does not expect clear law to dispense with the need for interpretation, as the brocard in claris non fit interpretatio would have us believe. Interpretation is always necessary: 'All laws, written and unwritten, have need of interpretation' (Leviathan, Ch. 26). ${ }^{124}$ No text is sufficiently clear that it avoids the risks of interpretation by an ignorant grammarian or a cavilling logician: ${ }^{125}$

not the letter (that is, every construction of it), but that which is according to the intention of the legislator, is the law (...) For it is not the letter, but the intendment, or meaning; that is to say, the

122 HOBBES 1840b, 106.

${ }^{123}$ HOBBES 2012, 432.

${ }^{124}$ HOBBES 2012, 430.

${ }^{125}$ HOBBES 1840b, 64. 


\section{Sílvia Alves |TheLastWolf| ISSN 2675-1038}

authentic interpretation of the law (which is the sense of the legislator)' (Leviathan, Ch. 26, 7). ${ }^{126}$

In Dialogue, Hobbes warns of the danger of judicial interpretation. He states that the judge-interpreter may, without danger, stray from the letter of the law, if he does not stray from the meaning or sense of the law, which a learned man (such as judges commonly are) can easily discover in the preamble, where the time the law was passed is found and the reasons why it was made. ${ }^{127}$ When he gives priority to logical interpretation ('that which the legislature thereby intended should be in force') over literal interpretation ('grammatical construction of the letter'), Hobbes identifies the elements of interpretation as the historical element or teleological element ('occasio legis' and 'ratio legis'). He recognises that the task of determining the sense of the law is difficult, requiring consideration of the circumstances that motivated and occasioned the law as a remedy ('conjuncture of occasions and incommodities, as needed a new law for a remedy') and obviously intelligence. ${ }^{128}$ In the context of a plural legal order, strange to an idea of system, where each source of law and each legal rule (royal, roman, canonical, customary law) incorporated its own logic, the systematic element largely and understandably escaped the perception of jurists.

Discussing the necessity of interpretation, the predominance of logical interpretation and the identification of the elements of interpretation, Hobbes elevates his considerations on the civil laws to a true general theory of interpretation.

e. When, in Dialogue, he reflects on situations where 'the true construction of the letter' is contrary to 'the meaning of the lawmaker', Hobbes begins

126 HOBBES 2012, 422 and 428.

${ }^{127}$ HOBBES 1840b, 7.

${ }^{128}$ HOBBES 1840b, 64. 


\section{Sílvia Alves |TheLastWolf| ISSN 2675-1038}

with the cases listed by Edward Coke ('fraud, accident, and breach of confidence') as an example of this discrepancy, but he considers that there are many more. He, above all, outlines their more general causes: the natural incompleteness of the legal order, considering that there are a great number of reasonable exceptions to almost every general rule that the lawmakers could not foresee, ambiguous words, and many doubtful connections between rules. ${ }^{129}$ These general considerations are similar to the concept of 'open texture' to which Herbert Hart alludes, but they lead Hobbes down a path that takes him to the other extreme, since he will never admit even the faintest judicial discretion, even if 'such a limited discricionary power'. ${ }^{130}$

f. Hobbes returns to arbitrium judicis in relation to the power to determine the penalties for each crime, rejecting the point of view of stoics for whom all crimes are equal, punishing the killing of a man and the killing of a chicken in like manner. He thus highlights the natural variability and political flexibility of punishments.

Just as Simplicius does in the Galileo Galilei Dialogue, the Lamyer describes the state of the art or the dominant view in the world of jurists: punishments for all crimes are fixed by the common law. That is, if the law ('statute') determines the penalty, the judge shall apply it; if the law does not so determine, custom is to be followed; if the case is a new one, he does not see why the judge may not establish the penalty in line with reason. ${ }^{131}$

The Philosopher asks: Whose reason? Natural reason cannot be the reason of judges - who receive their authority from the King, it will be remembered -, because there are as many reasons as judges and the

129 HOBBES 1840b, 65.

${ }^{130}$ HART 2012, 273 (Postscript).

131 HOBBES 1840b, 121. 
punishment of crimes would be uncertain. A certain penalty cannot correspond to the variable and subjective 'natural reasons' of judges. Or as Cesare Beccaria (1738-1794) would say: to the momentary bad mood ('attuale fermento degli umor') of judges. ${ }^{132}$ If natural reason truly established punishments, all over the world and in all times the same crimes would be punished with the same penalties, since reason is immutable and eternal. ${ }^{133}$ Uncertainty, insecurity, subjectivism, arbitrariness - the argument that Hobbes uses will be present in the eighteenth century reformist criticism and the debate on judicial discretion.

Regarding the use of the 'custom of punishing' certain crimes with certain penalties, Hobbes is not impressed with antiquity. A similar judicial custom or precedent does not have the 'force of law in itself, but is supported by a presumption that somewhere in the distant past there was a judgment of a King. The Philosopher prefers the most recent and fairest precedents ('the most immediate antecedent precedents'; 'the fairest warrants of their judgments'), just as he has a preference for new laws that are fresher in the memory of men. Contemporary law is tacitly confirmed inasmuch as the sovereign legislator does not disapprove it. ${ }^{134}$ Giving value to current law, which means above all giving value to statute law, represents a true revolution, which erupted in the century of codification and was painstakingly prepared in the second half of the previous century, when the idea of progress spread to the law.

g. Who should determine punishments? Who holds the 'trump' in this game? Regarding issues of government, Hobbes writes, if everyone is in an equal position, the trump card belongs to those holding clubs ('clubs are trumps'). In other words, he who has the force on his side, the sovereign. Because that power has to be given to those who can enforce it.

132 BECCARIA 1764, 13.

${ }^{133}$ HOBBES 1840b, 121 and 122.

${ }^{134}$ HOBBES 1840b, 125. 
Otherwise, it would be given in vain. ${ }^{135}$ Consequently, if there is no 'positive law' that establishes the penalty, or another order of the King, the latter must be consulted before a ruling is issued that orders irreparable harm, 'according as he shall judge most to conduce to the encouraging of men to serve the Commonwealth, or deterring of them from doing disservice to the same' (Leviathan, Ch. 18). ${ }^{136}$

Hobbes' argument is truly the argument of the future, which is still wielded today when the matter at issue is judges' discretionary power. Determining the penalty depends exclusively on the authority of the King because one thing is 'to make' the law, and another is to declare or 'pronounce' the law. ${ }^{137}$ In a similar expression by Montesquieu (16891755), the judge is the 'mouth' that pronounces the words of the law. ${ }^{138}$ Otherwise, he would be invading a territory that does not belong to him, usurping the power of the sovereign. The ruling would not be the judgment of the law, but the judgment of a man subject to the law. ${ }^{139}$

h. The belief that interpretation is a dangerous activity leads Hobbes to evidence a notable distrust regarding how jurists act in general and their liking for quibbling. All too easily, they would present various possible opinions on the best interpretations of the law and, at least when it had to be applied, it would be necessary to choose one of the resulting interpretations. Hobbes notes the difficulty of this process of creating possibilities and choice that was clearly beyond the will of the lawmaker. Authentic interpretation was the first means of avoiding the 'craftiness of interpreters'. The law must be clear but, if it is obscure, the lawmaker should remove the difficulty it created by clarifying the meaning of the

135 HOBBES 1840b, 122.

136 HOBBES 2012, 276.

${ }^{137}$ HOBBES 1840b, 124.

138 MONTESQUIEU 1748, 256.

${ }^{139}$ HOBBES 1840b, 127. 


\section{Sílvia Alves |TheLastWolf| ISSN 2675-1038}

law. Even so, the danger of the interpreter becoming the legislator remains.

The interpretation of all laws dependeth on the authority sovereign; and the interpreters can be none but those which the sovereign, to whom only the subject oweth obedience, shall appoint. For else, by the craft of an interpreter, the law may be made to bear a sense contrary to that of the sovereign, by which means the interpreter becomes the legislator (Leviathan, Ch. 26). ${ }^{140}$

In one of the passages of his work where he pronounces on the causes of an increase in lawsuits, Hobbes blames jurists and their methods. His analysis has a certain 'sociological tint' to it: is there a correlation between the amount of litigation and the number of lawyers? In Dialogue, Hobbes cites Edward Coke, who identifies six causes of the increase in the volume of judicial proceedings, including peace, prosperity and the large number of lawyers. ${ }^{141}$ Hobbes begins by laying the blame for this situation with those who have the power to admit lawyers into their profession or refuse them, but he quickly focuses on the 'art of cavilling against the words of a statute', which men appear to be increasingly versed in. The variety of points of view encouraged the appearance of futile or unnecessary cases and the hope of winning them. The adversarial nature of trials increased the expectation of gaining victory in actions that were void of grounds in terms of reason. Ignorance or lack of knowledge of equity led jurists to be guided more by precedents than by their own sense of justice ('in their own breasts'). Lastly, covetousness, which increased in peace times, meant lawyers had more leisure to study fraud. ${ }^{142}$

${ }^{140}$ HOBBES 2012, 428.

${ }^{141}$ HOBBES 1840b, 44.

${ }^{142}$ HOBBES 1840b, 45. 


\section{THE ENEMY}

a. Treason, rebellion, lèse-majesté: the most distinctive mark of behaviour so defined is a total break with the power and with its law. By acts or words, the subject 'wittingly and deliberately' denies the authority of the representative of the State (Leviathan, Ch. 28). ${ }^{143}$ While a common criminal breaks one or more laws without ceasing to recognise his sovereign and submit to his power and his laws, the traitor breaks totally and dramatically with the social covenant that led to a duty of 'absolute and universal obedience' to the 'sovereign power' and a special duty of obedience to all its laws (Philosophical Rudiments, Ch. 14, 20). ${ }^{144}$ Enemies are those who 'were either never subject to the law, and therefore cannot transgress it; or having been subject to it, and professing to be no longer so, by consequence deny they can transgress it' (Leviathan, Ch. 28). ${ }^{145}$

if such high-treason should take effect, it would destroy all laws at once; and being done by a subject, it is a return to hostility by treachery; and consequently, such as are traitors may, by the law of reason, be dealt withal as ignoble and treacherous enemies: but the greatest of other crimes, for the most part, are breaches of one only, or at least of very few laws (Dialogue). ${ }^{146}$

Rebellion means 'renouncing of subjection' and 'relapse into the condition of war' (Leviathan, Ch. 28). ${ }^{147}$ Because the end of the institution of power is the peace and defence of all, and considering that those who are entitled to an end are entitled to the means, the sovereign is the judge who determines the necessary means to ensure peace, and the causes of

143 HOBBES 2012, 486 and 494.

144 HOBBES 1841, 199.

145 HOBBES 2012, 486.

146 HOBBES 1840b, 72.

147 HOBBES 2012, 494. 
everything that may disturb or hinder it (Leviathan, Ch. 18). ${ }^{148}$ It is the prerogative of the sovereign to identity his enemies.

b. Hobbes includes within the crimen laesae majestatis the 'design, or act, contrary to a fundamental law' (Leviathan, Ch. 27) ${ }^{149}$ and by the latter it is understood 'that which, being taken away, the Commonwealth faileth and is utterly dissolved, as a building whose foundation is destroyed' (Leviathan, Ch. 26). ${ }^{150}$ The traitor does not recognise the powers of the sovereign, which include the right to create laws and establish punishments, and will not therefore benefit from the protection of the law which he himself denies. For the State, the expectation of finding a subject in him, even if a criminal subject, wains, because even the criminal will not cease to submit himself to the courts and to punishment. Crime is a mere 'irritation' of the established order or a 'repairable slip' ('reparierbarer Ausrutscher'). ${ }^{151}$ For the rebel, penalties are devoid of utility. The State will respond to this pure enemy bent on destruction with a single concern: elimination of the danger he represents. Treason becomes a purely political problem, outside of the law.

c. Hobbes considers high treason as a crime in itself ('malum in se'). It is not, therefore, the (civil) law but reason without law that makes the most serious of crimes. ${ }^{152}$ He presents his definition, despite listing behaviour of which it may be composed, making use only of 'natural reason'. The release of a certain legal casuism is a feature of modernity and at the same time a response to the way in which this crime had seen unprecedented expansion with the absolute monarchies. Safety is, once again, the key to

148 HOBBES 2012, 270.

149 HOBBES 2012, 478.

${ }^{150}$ HOBBES 2012, 448.

151 JAKOBS 2004, 91.

152 HOBBES 1840b, 70. 
the explanation, bringing together a long list of behaviour that falls under the label of lèse-majesté. Security and the common good of the people is the supreme law ('salus populi est suprema lex'), Hobbes reminds us in Dialogue, and then immediately adds: the safety of the people of a kingdom consists of the safety of the King and the strength necessary to defend his people, both against foreign enemies and rebellious subjects. ${ }^{153}$ The safety of the people is therefore achieved through the safety of the King and the possibility of the strength the King holds being directed against his people is not raised. The State is simultaneously the guarantor and the main creditor of safety and peace.

d. Rebellion is 'war renewed' (Leviathan, Ch. 28) ${ }^{154}$ and, therefore, a crime by the law of nature and not by the civil law (Philosophical Rudiments, Ch. 14, 20), ${ }^{155}$ notwithstanding some conduct which this has historically included. It breaks a former and older law, that imposes respect for the given word and therefore contracts (Philosophical Rudiments, Ch. 14, 21). ${ }^{156}$. The nature and consequences of the crime are transformed. Treason is war and develops outside the limits of the law. It is even beyond discretion, since this was admitted, regulated and limited by the legal order. Accordingly, Hobbes in some way presents grounds for the exceptional nature of the legal rules for the crime treason as a potentially unlimited exacerbation of the punishment and transferability of criminal liability. For Günther Jakobs he becomes a philosophical precursor to the criminal law of the enemy. ${ }^{157}$

Penalties are a privilege of the subject: harm inflicted on enemies cannot be considered true punishment but acts of hostility. Rebels and traitors are

153 HOBBES 1840b, 70.

154 HOBBES 2012, 494.

155 HOBBES 1841, 200.

156 HOBBES 1841, 200.

157 JAKOBS 2004, 89 and 90. 
punished not by civil law but by the law of nature, not as citizens but as enemies, not by the right of sovereignty but by the right of war (Philosophical Rudiments, Ch. 14, 22). ${ }^{158}$ 'The punishments set down in the law are to subjects, not to enemies' (Leviathan, Ch. 28). ${ }^{159}$

The state of war declared between the traitor and the State removes the limits on the resources that the State can use to combat it. The nature and measure of the penalties cease to be problems to be raised: 'in declared hostility all infliction of evil is lawful'. Whatever the punishment established for the treason, the representative of the State may 'lawfully be made to suffer whatsoever the representative will'. Because denying subjection to the power also denies its law, including the law's punishments, and 'therefore suffers as an enemy of the Commonwealth; that is, according to the will of the representative' (Leviathan, Ch. 28). ${ }^{160}$

The legitimacy to impose harm on the non-subject-enemy requires no more than a danger to the State or, more precisely, a danger that the representative considers exists: 'against enemies, whom the Commonwealth judgeth capable to do them hurt, it is lawful by the original right of nature to make war; wherein the sword judgeth not, nor doth the victor make distinction of nocent and innocent as to the time past, nor has other respect of mercy than as it conduceth to the good of his own people' (Leviathan, Ch. 28). ${ }^{161}$

There are no laws, or courts or innocent persons. While among subjects punishment of innocent men is not possible - because it is against the law of nature, and a manifestation of ingratitude and breach of equity (Leviathan, Ch. 28) ${ }^{162}$ - the State is free to inflict any evil on an innocent

158 HOBBES 1841, 201.

159 HOBBES 2012, 486.

160 HOBBES 2012, 486.

161 HOBBES 2012, 494.

162 HOBBES 2012, 492. 
man that is not a subject'. Vengeance can 'lawfully' be extended to innocent family members - 'not only to the fathers, but also to the third and fourth generation not yet in being, and consequently innocent of the fact for which they are afflicted' (Leviathan, Ch. 28). ${ }^{163}$

\section{DUTY TO OBEY AND LIBERTY TO RESIST}

a. The Hobbesian rationale for the inadmissibility of the right of resistance brings together two types of very different arguments. We find a number of logical conclusions which, although they ought to seem inevitable, are at the same time less convincing. The ultimate and most powerful argument is pragmatic and based on tradition. This less original argument is presented via a specific anthropology that cannot be considered as entirely pessimistic.

A mechanistic and deterministic understanding of human nature makes the behaviour of governments and the governed predictable and, consequently, allows politics to be transformed into science. And it provides trust in a new - yet precarious - balance, which makes disobedience unnecessary.

i) The sovereign cannot breach the social covenant

Subjects cannot be freed from subjection, under the pretext of breach of the social covenant, because, strictly speaking, such a transgression cannot be conceived. The covenant was not made between the subjects and the sovereign (Leviathan, Ch. 18), ${ }^{164}$ or between the people and the sovereign. ${ }^{165} \mathrm{~A}$ multitude of men agreed - 'every one with every

163 HOBBES 2012, 494.

164 HOBBES 2012, 266.

165 MERÊA 2004, 334. 
one' - to give by majority the right to represent the person of each of them' (Leviathan, Ch. 18). ${ }^{166}$

ii) The sovereign does no injury

By means of the social covenant, the subjects authorise all the actions and decisions of the representative - which may be a man or an assembly - as if they were their own acts and decisions, with the aim of living peacefully together and being protected from others (Leviathan, Ch. 18). ${ }^{167}$ Nothing that the sovereign does can therefore be considered injury to his subjects because these are, in fact, the authors of all the acts and decisions of their representative (Leviathan, Ch. 18). ${ }^{168}$ Governors, governance and the governed are considered a single seamless unit.

iii) The sovereign can neither be punished nor tried

Nothing that the sovereign does can be punished by the subject (Leviathan, Ch. 18). ${ }^{169}$ He enjoys total impunity (Elements of Law, Ch. 1, 12 and Ch. 8, 6). ${ }^{170}$ Even if he deserves punishment, this would always have to be preceded by a trial and the subject does not have such a power over his sovereign. Those who have sovereignty cannot be tried or justly be punished, and much less deposed or put to death. An opinion that admits tyrannicide is 'false and pernicious' (Elements of Law, Ch. 8, 10). ${ }^{171}$ Lord of impunity, the holder of power is not even obliged to obey his own laws; it would not make sense to consider someone who can abrogate the law to be subject to that law (Elements of Law, Ch. 8, 6). ${ }^{172}$

166 HOBBES 2012, 264.

167 HOBBES 2012, 264.

168 HOBBES 2012, 270.

169 HOBBES 2012, 270.

170 HOBBES 1840a, 132 and 205.

${ }^{171}$ HOBBES 1840a, 208.

172 HOBBES 1840a, 205. 
iv) Men transfer the right to resist

If men transfer to the sovereign the power to use force or 'power of coercion', they transfer with it the right to resist him (Elements of Law, Ch. $1,7) \cdot{ }^{173}$

b. Hobbes accepts that the condition of the subject is 'very miserable' and depends on the 'lusts' and 'other irregular passions' of those who hold so unlimited a power but, as bad as power is, the absence of power will always be a greater evil ... the State arises and is maintained through fear.

First of all, subjects must be aware that 'the estate of man can never be without some incommodity' (Leviathan, Ch. 18). ${ }^{174}$ But above all that incommodity will always be 'scarce sensible, in respect of the miseries and horrible calamities that accompany a civil war, or that dissolute condition of masterless men without subjection to laws and a coercive power to tie their hands from rapine and revenge' (Leviathan, Ch. 18). ${ }^{175}$ Nothing compares with the afflictions of the state of nature, where the life of man is 'solitary, poor, nasty, brutish, and short' (Leviathan, Ch. 13). ${ }^{176}$ The fear that maintains the civitas is not the fear of punishment, but the fear of returning to the state of nature. ${ }^{177}$ The rights of the sovereign 'cannot be maintained by any civil law or terror of legal punishment' (Leviathan, Ch. 30). ${ }^{178}$

Men will tend to attribute the cause of their ills to the form of government, but Hobbes does not allow them to be fooled, 'whereas the power in all forms, if they be perfect enough to protect them, is the same'

${ }^{173}$ HOBBES 1840a, 129.

174 HOBBES 2012, 282.

175 HOBBES 2012, 282.

176 HOBBES 2012, 192.

177 YATES 2012, 112.

${ }^{178}$ HOBBES 2012, 522. 
(Leviathan, Ch. 18) ${ }^{179}$ Hobbes' considerations on the suffering that power causes and how subjects understand those evils are primarily based on a pragmatic analysis of human behaviour. Men have a frightening tendency to understand their condition and their luck most irrationally. They tend to believe that the cause of their ills lies in the form of government; they tend to forget that any political change will in all likelihood lead them to the calamity of a return to the state of nature; with a fatal lens that distorts reality, they see every little effort increased to a 'great grievance' and are blind to see 'afar off the miseries that hang over them' (Leviathan, Ch. 18). ${ }^{180}$

This anthropological fatalism does not become pessimism, because, in relation to those who exercise power, the tendency to quibble and even prevaricate finds a natural limit. Subjects may count on the interest of those who govern in the force and glory of their subjects. If they are not foolish to the point of forgetting the advantages of maintaining everyone's hands tied, resistance will not be necessary. A balance of general utility between the governors and the governed will occur naturally.

The duty of the sovereign is to govern his people well. He may be the supreme judge of what is good for the people. His actions, all actions, may include the implicit consent of the subjects, who have transferred power to him. His poor governance, which transgresses the divine and natural law, may only be judged by God. But the benefit and good of the people is the supreme law (Elements of Law, Ch. 9, 1). ${ }^{181}$ Not only the mere preservation of their lives but in general their benefit, including the 'commodity of living', liberty and wealth (Elements of Law, Ch. 9, 3-4). ${ }^{182}$ Fortunately, the art and duty of those who govern are also their benefit.

179 HOBBES 2012, 282.

${ }^{180}$ HOBBES 2012, 282.

${ }^{181}$ HOBBES 1840a, 213 and 214.

182 HOBBES 1840a, 214-216. 
c. The aim of power - the peace of the subjects among themselves, and their defence against a common enemy (Leviathan, Ch. 21) ${ }^{183}$ - justifies its absolute nature but also the fissures in the right of obedience. In the social state the subject maintains the right to defend his life, his physical integrity and his liberty. This liberty to disobey to guarantee self-preservation is inalienable. A covenant in which someone covenants not to defend himself by force is always void. The promise of not resisting force does not transfer any right, nor is it obliging, because man always chooses the lesser evil, that is, he prefers the danger of death in resisting to certain death if he does not resist (Leviathan, Ch. 14; Philosophical Rudiments, Ch. 2, 18). ${ }^{184}$ A covenant always contemplates a benefit, which does not exist here. Nor should someone be understood to have promised such a thing or that this was his will (Leviathan, Ch. 14). ${ }^{185}$ The law of nature lays down: we will defend ourselves by all means we can (Leviathan, Ch. 14). ${ }^{186}$

This right to defence and resistance is exercised even against legitimate aggression, as is the case with a criminal conviction: 'If the sovereign command a man, though justly condemned, to kill, wound, or maim himself; or not to resist those that assault him (...) hath that man the liberty to disobey' (Leviathan, Ch. 21). ${ }^{187}$ For the same reason, a prisoner may lawfully escape by any means at his disposal (Leviathan, Ch. 21). ${ }^{188}$ If someone is interrogated concerning a crime he has committed, he has a real right to silence, since he is not obliged to confess it, unless he receives the guarantee of a pardon (Leviathan, Ch. 21). ${ }^{189}$ And a covenant in which

${ }^{183}$ HOBBES 2012, 336.

${ }^{184}$ HOBBES 2012, 214; HOBBES 1841, 26.

185 HOBBES 2012, 200.

186 HOBBES 2012, 202.

187 HOBBES 2012, 336.

188 HOBBES 2012, 344.

${ }^{189}$ HOBBES 2012, 338. 
someone promises to accuse himself is invalid (Leviathan, Ch. 14). ${ }^{190}$ This feature of the subject's right to defence is separate from the traditional right of resistance, which supposes unjust laws or an illegitimate power. It is an instrument used to limit power, just as natural law and the concept of justice have a primarily political aim. The Hobbesian right of resistance may, with originality, be exercised by a criminal who has been convicted in court, ${ }^{191}$ but not by the subject who is victimised by a government that causes him great afflictions, as long as it does not threaten his life, physical integrity or liberty. Hobbes, in fact, 'seems to have left a chink in the sovereign's armour - an opportunity for the re-emergence of the violent conflict of the state of nature'. ${ }^{192}$ The right to punish and the right to resist are the brutal remains of the state of nature.

d. The right to avoid death, injuries and incarceration belong in the 'tranquil reign of laws' ('il tranquillo regno delle leggi'), ${ }^{193}$ alongside the right to punish, ${ }^{194}$ but the right to disobey may also be lawfully exercised at times of rupture. In fact, the duty to obey lasts while 'and only while' remains the power by which the sovereign can protect the subject, who has a right to safety. Obedience is the counterpart of protection.

The 'sovereignty is the soul of the Commonwealth' (Leviathan, Ch. 21) ${ }^{195}$ and strength is its body. When the soul leaves the body, this means dissolution and death. He who has been a subject up to that point directs his obedience to where he finds protection. It may be his own sword or that of another. When the sovereign ceases to provide safety, the subject can, without treason, submit to the enemy victor.

190 HOBBES 2012, 214.

191 SOTO 2013, 701.

192 RISTROPH 2012, 116.

193 BECCARIA 1764, 67.

194 ANDÚJAR 2008, 102.

195 HOBBES 2012, 344. 
Sovereignty, like peace, is precarious. It is immortal only in the intention of those who create it. It is subject to violent death by a foreign war and, from its very institution, it contains many seeds of natural mortality, by 'intestine discord' (Leviathan, Ch. 21). ${ }^{196}$ It is, in fact, justice that gives life and continuity to States (Leviathan, Ch. 29). ${ }^{197}$

e. Hobbes' thinking contains an undeniable tension between the duty to obey and the right to resist that has rightly been considered an antinomy. While, on the one hand, he rejects the traditional right of resistance, on the other, he recognises the continuation of a natural right of defence and resistance to violence, even if lawful. It is safety that justifies the institution and the concentration of power and it is the protection of individuals that continues to justify that 'natural' disobedience. ${ }^{198}$ The admissibility of a territory of resistance produces a non-rectifiable contradiction in the construction of an absolute power, a political suicide. ${ }^{199}$ The balance appears to be tipped towards the individual who ceases to be a subject or becomes free from subjection when safety ceases to be provided. The individualist and egalitarian mark is attached when the State is born - it is not the people who make the social covenant but individuals, each one with his peer - and the (individual) liberty to disobey continues to be a threat. Hobbes "launches the "era of the individual". ${ }^{200}$ As fearsome as the monster Leviathan, this great man composed of a multitude of men, may be, the aim of power means that the individual is not totally stripped and there remains a certain latency of the state of nature. The liberty to disobey remains as a threat and the seed of its death. As Ernst Bloch (1885-1977) observed, Hobbes' absolutism, haloed 'Mephistophelianly', is

196 HOBBES 2012, 344.

197 HOBBES 2012, 498.

198 TZITZIS 1996, 66.

199 ZAFFARONI 2012, 11.

200 GOYARD-FABRE 1997, 64. 


\section{Sílvia Alves ITheLastWolf| ISSN 2675-1038}

found here, in such a strange manner, aligned to classic liberalism. ${ }^{201}$ Perhaps Hobbes was really a 'mistaken liberal'. ${ }^{202}$ In any case, one cannot but recognise that the professed individualism mitigates the practical consequences of his absolutism. ${ }^{203}$ The State, the monster, lives, after all, for men rather than men for the State.

201 BLOCH 1967, 63.

202 MONCADA 2006, 182.

203 TRUYOL Y SERRA 2007, 226. 


\section{REFERENCES}

ALVES, Sílvia, Punir e Humanizar. O Direito Penal Setecentista, Lisboa, 2014.

ANDÚJAR, Antonio Hermosa, "La doctrina penal de Hobbes", Fragmentos de Filosofia, 2008, 81-103.

AUSTIN, John, The Province of Jurisprudence Determined, Cambridge, 1995.

BECCARIA, Cesare, Dei Delitti e delle Pene, Monaco, 1764.

BLOCH, Ernst, Naturrecht und menscbliche Würde, Frankfurt, 1967.

CATTANEO, Mario, "Hobbes's Theory of Punishment", in: K.C. BROWN (ed.), Hobbes Studies, Oxford, 1965, 275-297.

DIDEROT, Denis, "Hobbisme ou Philosophie de Hobbes", in: Encyclopédie, on Dictionnaire raisonné des Sciences, Vol. VIII, Neuchâtel, 1765, 232-241. 
DWORKIN, Ronald, Law's Empire, Oxford, 1998.

GOYARD-FABRE, Simone, Les principes philosophiques du droit politique moderne, Paris, 1997.

HART, H. L. A., The Concept of Law, Oxford, 2012.

HOBBES, Thomas, Leviathan. 2. The English and Latin Texts, Oxford, 2012.

HOBBES, Thomas, The English Works of Thomas Hobbes of Malmesbury, Vol. II. Philosophical Rudiments concerning Government and Society, London, 1841.

HOBBES, Thomas, The English Works of Thomas Hobbes of Malmesbury, Vol IV. De Corpore Politico or the Elements of Law Natural and Politic, London, 1840.

HOBBES, Thomas, The English Works of Thomas Hobbes of Malmesbury, Vol VI. A Dialogue between a Philosopher and a Student of the Common Laws of England, London, 1840.

JAKOBS, Günther, "Bürgerstrafrecht und Feindstrafrecht", HRRS, 2004.3, 88-95. 
LOBBAN, Michael, "Thomas Hobbes and the common law", in: David DYZENHAUS and Thomas POOLE (eds.), Hobbes and the Law, Cambridge, 2012, 39-67.

MARTYN, Georges, "From Arbitrium to Legality? Or Legality and Arbitrium?", in: Georges MARTYN, Anthony MUSSON and Heikki PIHLAJAMÄKI (eds.), From the Judge's Arbitrium to the Legality Principle, Berlin, 2013, 7-31.

MERÊA, Paulo, "Suárez. Grócio. Hobbes”, in: Paulo MERÊA, Estudos de Filosofia Jurídica e de História das Ideias Políticas, Lisbon, 2004, 329-347.

MONCADA, Luís Cabral de, Filosofia do Direito e do Estado, Vol. I, Coimbra, 2006.

MONTESQUIEU, De l'Esprit des Lois, Geneva, 1748.

NORRIE, Alan, "Thomas Hobbes and the Philosophy of Punishment", Law and Philosophy, 1984, 299-320.

PUFENDORF, Samuel von, Le Droit de la Nature et des Gens, Vol. II, Amsterdam, 1706.

RISTROPH, Alice, “Hobbes on 'Diffidence' and the Criminal Law", in: Markus D. DUBBER (ed.), Foundational Texts in Modern Criminal Law, Oxford, 2014, 23-37. 
RISTROPH, Alice, "Criminal law for humans", in: David DYZENHAUS and Thomas POOLE (eds.). Hobbes and the Law, Cambridge, 2012, 97-117.

RISTROPH, Alice, "Respect and resistance in Punishment Theory", California Law Review, 2009, 601-632.

SCHROCK, Thomas S, "The Rights to Punish and Resist Punishment in Hobbes's Leviathan", The Western Political Quarterly, 1991, 853-890.

SOTO, Carlos Isler, "Las Bases Filosóficas de la Doctrina Penal de Thomas Hobbes", Revista de Estudios Histórico-Jurídicos, 2013, 681-706.

TRUYOL Y SERRA, Antonio, Historia de la Filosofía del Derecho y del Estado. 2. Del Renacimiento a Kant, Madrid, 2007.

TZITZIS, Stamatios, La Philosophie Pénale, Paris, 1996.

TZITZIS, Stamatios, "La Philosophie de la Peine chez Thomas Hobbes", Archives de Philosophie du Droit, 1984, 283-304.

VILLEY, Michel, Philosophie du droit. Définitions et fins du droit. Les moyens du droit, Paris, 2006.

VILLEY, Michel, La formation de la pensée juridique moderne, Paris, 2003. 
YATES, Arthur Lansing, Thomas Hobbes on Punishment, thesis submitted for the degree of PhD in Philosophy, Western London University, Ontario, 2012.

ZAFFARONI, Eugenio Raúl, El Leviathan y el Derecho Penal, 2012, perso.unifr.ch/derechopenal/documentos/artículos/a_20120808_01.pdf (accessed 9 February 2020).

ZAFFARONI, Eugenio Raúl, Apuntes sobre el Pensamiento Penal en el Tiempo, Buenos Aires, 2007. 